$1-1-2003$

\title{
"Race to the Bottom" Returns: China's Challenge to the International Labor Movement
}

Stephen F. Diamond

Santa Clara University School of Law, sdiamond@scu.edu

Follow this and additional works at: http://digitalcommons.law.scu.edu/facpubs

Part of the Labor and Employment Law Commons

\section{Recommended Citation}

10 U. C. Davis J. Int'1 L. \& Pol'y 39 (2003-2004)

This Article is brought to you for free and open access by the Faculty Scholarship at Santa Clara Law Digital Commons. It has been accepted for inclusion in Faculty Publications by an authorized administrator of Santa Clara Law Digital Commons. For more information, please contact sculawlibrarian@gmail.com. 


\title{
The "Race to the Bottom" Returns: China's Challenge to THE INTERnAtional LABOr MOVEMENT
}

\author{
Stephen F. Diamond*
}

TABLe of Contents

I. InTRODUCTION ................................ 39

II. China's Economy at a Turning Point $\ldots \ldots \ldots \ldots .48$

III. Chinese Trade Unionism....................... 55

IV. The International Legal Arena ............... 65

V. Global Labor's Approach to China............. 68

\section{INTRODUCTION}

In the early morning of March 3, 2003, two young women, Yao Dan and Xiao Yu, were sitting in a Beijing hotel room when 20 officers of the Chinese Public Security Bureau burst in and detained them. Their crime? They were in Beijing to attempt to meet with the defense lawyer representing Xiao Yu's father, Xiao Yunliang. Xiao Yunliang had been tried several weeks earlier along with Yao Dan's father, Yao Fuxin, for allegedly "subverting the political power of the [Chinese] state." Both men were arrested in connection with their participation in a labor protest that had occurred a year earlier in the industrial town of Liaoyang in northeast China. ${ }^{1}$ But that was not the reason given to the women for their detention, according to the independent and widely respected China Labour Bulletin of Hong Kong.2 They were told, absurdly, that the hotel they were staying in was "too shabby," and that

* Assistant Professor of Law, Santa Clara University School of Law; Visiting Assistant Professor of Law, Cornell Law School, 2003-2004; J.D., Yale, 1994; Ph.D., London, 1991; B.A., University of California, Berkeley, 1977. The author wishes to acknowledge the valuable research assistance provided by Marilee Chan in the preparation of this article.

1 Criminal Verdict: Yao Fuxin and Xiao Yunliang (Intermediate People's Court of Liaoyang Municipality, Liaoning Province, May 9, 2003) translated in The Liaoyang Workers' Struggle: Portrait of a Movement, ChINA LAB. Bull., July 2003, at 71, available at http://www.china-labour.org.hk (on file with author) [hereinafter Liaoyang Workers' Struggle].

2 Descriptions of these events are found in Press Release, Human Rights in China, Liaoyang Labor Activists' Daughters Detained (Mar. 3, 2003) and Liaoyang Workers' Struggle, supra note 1, at 26. 
they would be taken to another hotel and allowed to meet with Xiao's lawyer. Instead they were taken to yet another location in the city where they were held while their possessions were searched. They were then driven back to Liaoyang in a police van accompanied by eight police officers, held separately in a government office and questioned for several hours. Before their release, the police requested they sign a doctored transcript of the interrogation including a statement that the purpose of their visit to Beijing had been, "to talk to foreign news media." Three months later the Intermediate People's Court of Liaoyang Municipality duly announced that the fathers of both women had been convicted of their "crime" and sentenced Yao to seven years, and Xiao to four years, in prison with an additional two-year period for each in which their "political rights" are to be suspended. ${ }^{3}$

As it turned out, the women were probably mostly guilty of bad timing. Their visit to Beijing happened to come just before the opening of the Chinese National People's Congress and the National People's Political Consultative Conference that were both engaged in sensitive discussions and negotiations about the transfer of power to a new generation of Chinese leaders. ${ }^{4}$ But why would that cause the police to be so concerned about the attempt of these women to meet with the lawyer representing one of their fathers? Was Beijing attempting to send a signal about the right of counsel in the new China? No. It appears far more likely that this event signals the fear and sense of fragility that grips the Chinese leadership. The fathers of these two women had been active in one of the most important worker protests among many thousands of such protests that have swept through China in the last few years. When originally arrested the two men were threatened with the death penalty. Only an international campaign of solidarity and further protest by fellow workers succeeded in getting the Chinese regime to reduce the sentence. The convictions of these worker activists for engaging in what much of the rest of the world would consider mild social protest, together with the harassment of their families for attempting to engage legal counsel, highlight the true state of labor relations and of the law in modern China.

Unfortunately this is no longer a phenomenon that can be viewed from a distance. China is now, and increasingly, an integral player in the global economy and in international relations. The detention and harassment of Yao Dan and Xiao Yu indicate what is at stake: economic and political restructuring in China today is affecting the lives of millions, yet only a small number of top bureaucrats and wealthy regime-backed entrepreneurs are making the basic decisions about the outcome of this

3 Liaoyang Workers' Struggle, supra note 1, at 71.

4 Human Rights in China, supra note 2. 
process. This bureaucratic and entrepreneurial class resists fiercely any serious attempt to build independent and democratic institutions such as trade unions. If this means exposing the regime as hypocritical about its commitment to the rule of law in China, they seem willing to take the political heat.

The globalization process that has done so much to integrate the Chinese economy into the world economy has only encouraged the regime. Japanese, Korean, Taiwanese, European and American corporations are fighting tooth and nail to take advantage of the changes underway in China. They see China as offering the world a vast pool of relatively cheap labor that comes not a moment too soon as declining profitability has hit returns to investors in the advanced economies. According to official government statistics, China's urban population has more than quadrupled since the early $1.950 \mathrm{~s}$, whereas its rural population has only increased from 503 to 866 million. ${ }^{5}$ This massive population shift is contributing to a significant unemployment problem. And that, in turn, is the cause of widespread social unrest. The Chinese Communist regime views this unrest as subversive of their entrenched power. Thus, rather than being concerned that the violation of universally recognized civil liberties such as the right of access to legal counsel and the freedom of association is the source of increased tension with the outside world, the regime views these violations as the solution to a significant problem facing the global economy. The international labor movement has struggled for more than a century to establish basic human rights, including labor rights, as an inviolable floor beneath which the world could not sink. Unless the labor movement and the world community as a whole confronts China directly with an alternative path of economic and political development, the integration of China into the global economy puts that century-long achievement at great risk.

The emerging Chinese model-a "socialist market economy" according to the regime itself-represents a new stage in the evolution of post Cold War global capitalism. The core principle of this model is the so-called "race to the bottom" where global multinational corporations ally with repressive developing country governments to combine high productivity manufacturing and services with cheap labor at the expense of unionized workers in developed economies. Free market advocates typically attempt to reduce the idea of a "race to the bottom" in global labor conditions to a caricature. If there really were a race to the bottom, they ask, then why are there so few multinationals operating in central Africa or countries like Haiti, where wages are indeed the lowest in the world? It is certainly true that capital is reluctant to invest in

51998 China Statistical Yearbook (China Stat. Info. \& Consultancy Service Centre) at 105. 
countries like Haiti or Rwanda, though such countries have long been the source of vital natural resources and agricultural products for global multinationals. It is also true that an examination of cross-border trade and investment flows demonstrates that the vast majority of such flows are between developed economies, not between the developed and developing world. ${ }^{6}$

But that misstates the problem. The "race to the bottom" defines a different and new issue: the ability of sophisticated multinational corporate capital to combine high-productivity technology with labor that is paid substantially less than that found in the developed world. Developing this dynamic is not as simple as finding the worst-paid and most-repressed workers in the world. What one finds, in fact, in countries like Haiti or Rwanda are not workers in the classic senseready and available to be part of the disciplined structure of a modern capitalist firm. In large part the populations of those countries are at a near-feudal level of development, with the "workforce" resembling peasants, not modern workers. The difference in China or Mexico or Indonesia is that decades of rule there by modernizing authoritarian states has produced a new kind of workforce that is akin to that found in Europe or the United States, but at a wage level far below that of the advanced economies and without the independent political power that characterizes countries with strong labor movements.

The "race to the bottom" is, in fact, what Harley Shaiken calls "high productivity poverty." This "isn't the poverty of Haiti or Bangladesh," Shaiken argues, "where industry is antiquated and the societies and people are poor. ... The problem isn't developing countries attracting advanced manufacturing, but rather that wages aren't simply low; they are artificially depressed. The law or the club-or both-are used to prevent workers from sharing the gains. ... [T] he historic link between workers producing more and earning more is tragically reversedworkers produce more and earn less." ${ }^{8}$ Financial analyst Richard Duncan confirms this trend:

Almost any labor-intensive product that can be made in the United States, Western Europe or Japan can be made at considerably less cost in China or a dozen other low-wage nations. Impediments once thrown up by transportation problems or capital shortages have long since been overcome by technological developments and the removal of capital

6 See Paul Hirst \& Grahame Thompson, Globalization in Question: The INTERnATIONAL ECONOMY AND THE POSSIBILITIES OF GovernanCE (1996).

7 Nancy Montwieler, 'High Productivity Poverty' Threatens Workers Labor, Professor Warns Machinists Meeting, DaILY LAB. ReP., Sep. 13, 2000, at C-1.

8 Id. See also, Harley Shaiken, Mexico in the Global Economy: High Technology and Work Organization in Export Industries (1990). 
controls. Today, the most capital-intensive manufacturing processes can be financed and built in any number of developing countries, so that the most advanced facilities can be combined with the lowest-cost labor.'

This break in the link between productivity and wages is the key to understanding the phenomenon known widely as the "race to the bottom." The creation of that link was the result of decades of effort by the international trade union movement. In the late 1920s and 1930s it led economists to speak of a new development: wage rigidity. This was the reflection in economic theory of the power of trade unions in a business downturn. It led John Maynard Keynes to conclude that the normal process of wages falling to a market-clearing price, often referred to as "Say's Law" as Keynes understood it, no longer functioned. ${ }^{10}$

But today China's entrance into the world economy represents the attempted integration of nearly a billion new workers into the global labor market at wages far below those found in the advanced economies. This signals the return of a world that operates according to Say's Law because the constraints on free markets, such as "wage rigidity" and the union power reflected in an effective international labor rights regime, may dissolve. As one leading Wall Street economist told his clients:

China's labor force is bigger than that in all of the OECD countries combined. Its rapid development has caused dramatic shifts in relative factor prices in a short period of

9 Richard Duncan, The Dollar Crisis: Causes, Consequences, Cures 144 (2003).

10 John Maynard Keynes, The General Theory of Employment, Interest AND MONEY 26 (1964). There is enormous controversy within the field of economic history on the actual definition of Say's Law and on Keynes' interpretation of it. In fact, the Law itself is better understood as the "law of markets"-which holds that where there is no "interference" with the markets they will find an equilibrium whereby all output can be sold. Only what W.H. Hutt called "defects in pricing" can interfere with the exchange of all output for other goods and services. W.H. HuTt, A ReHABILITATION OF SAY's LAW 8 (1974). But there is very little controversy about what Keynes meant on a substantive level, that the power of the labor movement constrained the ability of the private sector and the government to use wage cutting as a means of jumpstarting economic growth in a depression. "To suppose that a flexible wage policy is a right and proper adjunct of a system which on the whole is one of laissez-faire, is the opposite of the truth. It is only in a highly authoritarian society, where sudden, substantial, all-round changes could be decreed that a flexible wagepolicy could function with success. One can imagine it in operation in Italy, Germany or Russia, but not in France, the United States or Great Britain." Keynes at 269. Recall, of course, that this was when fascism or Stalinism ruled the first set of states, while democracy continued to function in the latter set. Hutt expressed the more traditional laissez-faire view that the power of unions was a key "defect in pricing" rather than the inevitable byproduct of modern capitalism. HuTr at 134-144. On Say generally, see Evelyn L. Forget, The Social Economics of Jean-Baptiste Say: MARKeTS AND VIRTUE (1999). 
time. Some of the changes will be permanent even with China's maturity. The most important one is that the value of labor will be permanently devalued against scarce resources. This is likely to have far-reaching consequences to the distribution of income in the world. The speed comes from the fact that the labor productivity gap between China and the mature economies is far less than the wealth gap between them. . . China's reintegration into the global economy, therefore, presents a major discontinuity. The gaps between China and developed economies for productivity and for wealth are expressing themselves through rapid capital reallocation from mature economies to China and the consequent rapid growth of China's exports. The key driver is China's low wages resulting from its vast surplus labor and low level of wealth. ${ }^{11}$

Far from being an anomaly, then, the arrest and conviction of Chinese labor activists, the harassment of their families for attempting to meet with legal counsel, and the violent suppression of democratic institutions such as free trade unions and independent political parties, represent a stark, if not dark, future for the global system. In fact, the effort to move the world in this direction has been given significant support by attempts to change the basic structure and purpose of central international institutions such as the International Labor Organization ("ILO") and the World Trade Organization ("WTO"). Such a conclusion runs counter to the arguments made about the nature of political and economic reform in China today. For the most part, supporters of the Chinese restructuring process argue that the market reforms underway there today will naturally create an opening for political pluralism and, eventually, a genuine rule of law and democratization. ${ }^{12}$ This viewpoint is reflected inside the international labor movement itself by those who argue that the trade union movement should begin a process of "constructive engagement" with the government-controlled All-China Federation of Trade Unions ("ACFTU"). ${ }^{13}$ The view held by some westerners that China will evolve towards democracy simply because it undertakes market reforms and the subset of this view held by some within the western labor movement that China's state-controlled labor organization, the ACFTU, will begin to, or

11 Andy Xie, Asia Pacific: The Chinese Decade, Morgan Stanley Global ECON. F., Feb. 10, 2003.

12 Henry M. Paulson, Jr., More Than the Bloom of One I.P.O., N.Y. Times, Apr. 15,2000 , at 17.

13 Kent Wong \& Elaine Bernard, Labor's Mistaken Anti-China Campaign, New LAB. F. (Fall/Winter 2000) ("Labor needs to encourage critical engagement with China. ... [L]abor leaders should take a bold step and seek to open up dialogue and cultivate relationships with workers and trade unions [sic] in China."). 
already does, behave like a genuine trade union and thus helps reinforce the alleged evolution towards democracy, is viewed as naïve by longtime specialists in Chinese politics and labor issues. ${ }^{14}$ Such views may, in fact, reflect changing attitudes towards democracy and labor rights in the West as much as they do a genuine assessment of the current situation in China.

This article will take its lead from the actions of the Chinese regime itself. The regime's fear that the mere presence of two young women in Beijing trying to meet with a lawyer representing their labor activist fathers suggests that there are two major issues of concern to the Chinese regime: law and labor. Thus, at the level of law, the focus will be on the changes that have taken place in the WTO and the ILO that are reinforcing the emerging Chinese model. China entered the WTO after a bitter political battle between the American trade union movement, on the one hand, and nearly the entire U.S. political and business establishment, on the other. But this could only be accomplished by the codification of a certain new approach to international labor rights in both the WTO and the ILO. This article will argue that this new approach has actually created a legal pathology that only postpones resolution of the real problems associated with the Chinese model. It is an unstable compromise that conflicts with other principles at work in the international legal environment. ${ }^{15}$

These international legal developments are being met domestically within China by an attempt to impose a new regime on the Chinese working class. This new regime relies on the same heavy-handed authoritarian measures that have long been constituent elements of modern Chinese politics. In the past the Chinese Communists justified such measures by the alleged need to resist the encroachment of capitalism, while now the Party defends the same authoritarian approach

14 Minxin Pei, Don't hold your breath for openness in China, Fin. TIMEs, May 7, 2003 at 15 (discussing "sclerotic authoritarian regime syndrome" that afflicts Chinese leaders); ACFTU-ICFTU: A Modern Love Story in the Making?, 52 China Lab. BuLL., Jan.-Feb. 2000, available at http://www.china-labour.org.hk (last visited Aug. 4, 2003; on file with author) (noting that "aspirations of the international trade union movement and the international work of the ACFTU stand contrary to each other").

15 E.g., International Covenant on Economic, Social and Cultural Rights, pt. III, art. 8(1)(a), opened for signature Dec. 16, 1966, G.A. res. 2200A (XXI), 21 U.N.GAOR Supp. No. 16, at 49, U.N. Doc. A/6316 (1966) (entered into force Jan. 3, 1976) recognizes the right of individuals "to form trade unions and join the trade union of his choice. . . [and] the right to strike" [hereinafter ICESCR]. See Aaron N. Lehl, China's Trade Union System Under the International Covenant on Economic, Social and Cultural Rights: Is China in Compliance with Article 8?, 21 U. Haw. L. REv. 203, 226 (1999). The ICESCR is, in some ways, stronger than the ILO Declaration as it not only incorporates the crucial principle of freedom of choice of labor organizations but also recognizes the right to strike. 
as necessary to succeed in the capitalist world. These developments feed each other. As accommodations are made to undemocratic approaches to human rights in international institutions, those elements in countries like China that see a shortcut to wealth and power through authoritarianism are encouraged to continue to suppress democratic movements. In addition, there is an unhealthy feedback into the advanced economies as the "race to the bottom" undermines the ability of those economies to provide better wages, hours and working conditions in industries that compete with Chinese authoritarianism. Thus, the international labor movement may have the most to lose among an array of democratic institutions. Even commentators reluctant to embrace the idea of a "race to the bottom" in the global market pause when they consider the overwhelming impact of China. ${ }^{16}$ An example from just one industrial sector-textile, clothing and footwearillustrates the problem. While throughout the 1990s the number of people working in this industry remained stable at 30 million, Cynthia Williams has noted, "there has been a dramatic shift in the distribution of those jobs towards Asia," with that region now accounting for 72 percent of world employment in the sector and China alone 20 percent. Meanwhile, employment in Europe and the United States in that sector "fell steadily throughout 1990-1998." Williams refers to an ILO study that notes that the average hourly wage rate in the industry ranges from a high of $\$ 10$ an hour in Europe to a low of $\$ 0.45$ an hour in China. ${ }^{17}$

But if labor loses so does democracy. The trade union is a central force for democratization, transparency and social responsibility in a modern industrial economy. Without the ability to form effective trade unions, workers cannot be said to enjoy fundamental human rights such as the freedom of association or the freedom of speech or the right to have grievances heard and redressed. Without an effective labor movement there is no counterweight to the power of business interests or volatile market forces in society or to the state itself. The power of the market to force new forms of brutal competition can easily take hold, generating deep political conflict and social unrest. Equally possible is the emergence of a Leviathan state that suppresses human freedom. In

16 William B. Gould IV, Labor Law for a Global Economy: The Uneasy Case for International Labor Standards, 80 NEB. L. REv. 715 (2001) ("there is no evidence of a 'race to the bottom' internationally in the labor arena" but "there are substantial arguments for international regulation" because "the outlier countries coupled with China make it possible that the 'race to the bottom' phenomenon could yet become a pressing one").

17 Cynthia A. Williams, Corporate Social Responsibility in an Era of Economic Globalization, 35 U.C. Davis L. Rev. 705, 731 (2002), citing Press Release, ILO, Global Employment Levels in Textile, Clothing and Footwear Industries Holding Stable as Industries Relocate (Oct. 16, 2000), available at http://www.ilo.org/public/ english/bureau/inf/pr/2000/38.htm. 
fact, as this article should demonstrate, this is precisely why exploring the process of economic reform in China is so important. The economic changes underway there are creating huge new inequities and imbalances. This is now leaking into the international arena as China's cheap labor export-led model of growth has generated a massive trade imbalance between China and the United States. As the presidential elections approach this is becoming an increasingly important problem in domestic U.S. politics. Thus, this article will argue, there is a need to articulate an alternative model that restores the role of democratic institutions as a counterweight to Say's "law of markets."

To explore these issues, this article will consider four areas of concern. First, the structural changes underway in the Chinese economy are creating both domestic and international imbalances that exacerbate inequalities among Chinese workers and create new inequities in the global labor market. Second, the Chinese regime's approach to labor rights remains rigidly authoritarian and, as a result, it is triggering ever more dramatic confrontations between workers and the Chinese state, despite the regime's nominal commitment to "socialism." Third, these developments are being reinforced by a pathological evolution in the principles that govern key international institutions such as the WTO and the ILO. A conflict has emerged within the international legal arena between the founding principles of these institutions and their current approach to labor and human rights issues. Fourth, within the international labor movement itself a small current is emerging which views an accommodation with the Chinese regime as a feasible alternative to the long-standing support of the international labor movement for independent and free trade unionism in China. This approach threatens the credibility of the labor movement's opposition to the most damaging aspects of the globalization process, a major commitment of organized labor at least since the "Battle of Seattle" that took place at the failed ministerial conference of the WTO in November 1999. ${ }^{18}$

These four developments militate in favor of the need to reassert core principles of labor solidarity but these must not just be mindlessly repeated. These developments signal a new form of global capitalism that increasingly sees authoritarianism as having a natural role in a modern economy. The unquestioned acceptance of the outcomes of the "law of markets," no matter how volatile, uneven, or unjust, now appears to be the norm as social movements and democratic institutions are rendered a nearly mute Greek chorus. Thus critics must take into

18 See Stephen F. Diamond, Bridging the Divide: An Alternative Approach to International Labor Rights After the Battle of Seattle, 29 PEPP. L. REv. 115, 117 (2001 [hereinafter Bridging the Divide]. 
account the new forms of capitalism and the power of its norms as it devises alternatives. Restoring the validity of questioning outcomes and thus of the value of social input and control of those outcomes must lie at the heart of these alternatives. This means that support, for example, for labor rights in China must go beyond the typical anti-Stalinist rhetoric that labor has used in the past. While the Chinese regime may fear the emergence of a Polish Solidarity-style movement, the labor movement must also learn from the mistakes and limits of the Solidarity experience.

\section{China's Economy at a Turning Point}

It is hard to overstate the magnitude of the changes underway in China today. While still only accounting for 5 percent of global manufactured exports in 2002, according to Morgan Stanley chief economist Stephen Roach, China nonetheless accounted for 29 percent of that year's growth in that sector. ${ }^{19}$ This remarkable development is the result of twenty years of economic policy change in China. In the early Eighties, the regime partially freed up prices in the agricultural sector and allowed farmers to retain a portion of their profits. This, in turn, unleashed pent-up demand for consumer goods, and so the regime went one step further, endorsing the new light industry and consumer goods businesses that began to emerge in the rural townships and villages. What one observer called an "extraordinarily virtuous economic circle" emerged whereby higher prices for food stimulated demand for basic consumer products like bicycles, televisions, and refrigerators and, increasingly, for light industrial goods such as tractors. ${ }^{20}$ This process sustained growth rates averaging 9 percent for most of the 1980s..$^{21}$ Nonfarm employment tripled from thirty million to ninety-three million people in that decade alone, with some sixteen million new rural businesses established. ${ }^{22}$

These new entities are seen by western Sinophiles as evidence of the emergence of a new private entrepreneurial class in China allowing the country, in the words of mainstream economist Barry Naughton, to "grow out of the Plan." ${ }^{23}$ But many of these new firms were formed with

19 Stephen Roach, Global: China - Externally or Internally Driven?, MORGAN Stanley Global Econ. F., April 2, 2003.

20 Joe Studwell, The China Dream: The Quest for the Last Great UNTAPPED MARKET ON EARTH 34 (2002).

21 Id. at 38.

22 Id. at 34.

23 Barry Naughton, Growing Out of the Plan: Chinese Economic Reform 1978-1993 (1995); John McMillan \& Christopher Woodruff, The Central Role of Entrepreneurs in Economic Reform (2002) (unpublished paper, on file with author); John McMillan, China's Nonconformist Reforms (1994) (unpublished paper, on file with author). 
local state and party official endorsement and participation. They have become a new competing power center in Chinese society, absorbing scarce financial resources. They are also the source of huge new income inequalities. Although the country has indeed registered huge gains in national income during the last twenty years, the gains have not been equally reflected in the personal income of ordinary Chinese households. In an articulate and thorough study entitled Inequality and Poverty in China, economists Azizur Khan and Carl Riskin take careful aim at the impact of market reforms and find the results disturbing. ${ }^{24}$ Communist Party reformer Deng Xiaoping had declared "let some get rich first" and the lucky few have done so with a vengeance. Khan and Riskin note that "between 1988 and 1995 inequality in the distribution of income in China increased sharply [as] China [became] one of the more unequal of the Asian developing countries." Thus, despite the impressive macro-level gains of the 1980s, as the 1990s unfolded there was, this study concluded, "an unusually rapid widening of income inequality ... a much retarded rate of poverty reduction in the countryside ... and a significant increase in absolute poverty in the towns and cities." In rural China, the Township and Village Enterprises (TVEs) have actually worsened income inequality as the enterprises offer higher wages but to only a small portion of the newly available workforce of former peasants, who are mostly forced to survive at or below the poverty line on whatever their backyard plots of land can produce.

Nonetheless, despite its apparent growth, the new so-called private sector does not have anywhere near the resources to meet the huge industrial needs of Chinese society. The single largest fully private entity in China has annual revenues of $\$ 600$ million, half the turnover of the 1000th company on the Fortune 1000 list. $^{25}$ Even today the private sector contributes only one-eighth of the nation's gross domestic product and employs less than twenty million workers in a nation of 1.2 billion people. In any case, the apparent economic miracle began to slow precipitously after the initial boost in the 1980s. In the early 1990s, it was discovered that the TVEs "had overstated production by more than $\mathbf{4 0}$ percent[,]" wiping out $\$ 100$ billion from the country's national income accounts. ${ }^{26}$ Much of the actual gain in GNP has been created by the regime's continued reliance on heavy capital investment, thus only exacerbating inequality and poverty. Khan and Riskin identify what is called "investment hunger," especially among local governments that are now less constrained by Beijing as the early stages of the reform process

24 See generally Azizur Rahman Khan \& Carl Riskin, Inequaltry and Poverty in China in the Age of Globalization (2001).

25 Studwell, supra note 20, at 229; The 2003 Fortune 500, Fortune, Apr. 14, 2003, available at $\mathrm{http}: / / \mathrm{www}$. fortune.com (last visited Dec. 4, 2003).

26 Id. at 231-32. 
loosened the grip of national power. ${ }^{27}$ "The state allowed an expansion of credit to pump up accumulation and drive a wedge between growth of GDP and that of personal income." 28

Despite the pace of reform, China's state-owned enterprises, or SOEs, still control the "commanding heights" of the economy in industries like steel, oil, and automobile assembly. In contrast to the still-tiny private sector, China's two state-owned oil companies together have revenues of more than $\$ 80$ billion and are comfortably placed on Fortune magazine's Asia's Top 50 list. $^{29}$ In the state sector, one finds that instead of the massive privatization that took place in the former Soviet Union with such disastrous effect, the regime has tried only partial privatizations, while continuing to feed these enterprises massive amounts of credit, recycling the savings of China's billion people into outdated and poor-performing industrial behemoths. China, in fact, actually seems committed more than ever to state control of key economic sectors. ${ }^{30}$

Many of these enterprises are truly out of a different age-the age of Soviet-influenced heavy industry or the American variant, the massive auto complex at Ford's River Rouge. These plants were, like their Soviet, American or Eastern European counterparts, impressive achievements-fifty years ago. But in the context of industry today, they are bankrupt. The regime thus finds itself in a trap of its own making. Having created this heavy industrial base, it has also created a massive industrial working class-or rather its new post-revolution working class created this massive industrial base, through the use of the most brutal forms of forced labor in the 1950s and 1960s. ${ }^{31}$ But to restructure now in a fashion that would allow these companies to be globally competitive would require huge layoffs and huge new capital investment. In the spring of 2000 , for example, the regime restructured its large state oil industry and attempted an initial public offering ("IPO") of shares in the newly formed PetroChina to global investors, including a listing on the New York Stock Exchange. To make the PetroChina IPO even barely credible to global capital markets required the layoff of hundreds of thousands and a promise to push billions in debt back to the state

27 KHAN \& Riskin, supra note 24, at 105.

28 Id. at 151.

29 Asia's Top 50, Fortune, Jul. 21, 2003, available at http://www.fortune.com (last visited Dec. 4, 2003).

30 Barry Naughton, Opening the Red Box: Explaining Economic Policy Regimes in China, Walter Shorenstein Forum, Asia/Pacific Research Center, Stanford University, Feb. 6, 2003.

31 See Nigel Harris, The Mandate of Heaven: Marx and Mao in Modern China (1978). 
through PetroChina's parent company, China National Petroleum (CNPC), which remained entirely in state hands. ${ }^{32}$

The only way that the regime believes it can preserve its own power in this process is to "muddle through," in Joe Studwell's words. ${ }^{33}$ Thus, the regime allows foreign companies to set up assembly plants in the special economic zones in coastal areas and, in the niches not already occupied by the state sector, encourages a limited domestic private sector to evolve from below. But it cannot allow the resulting inequalities and poverty this process causes to become so extreme that workers revolt. The regime fears a social explosion, called by the Chinese da luan or total chaos, a fear made real by the labor insurgency that took place in the spring of 2002 in the oilfields run by PetroChina and in the industrial zone of Liaoyang. ${ }^{34}$ The pall of Hungary in 1956 and Poland in 1980 continue to hang over the Chinese Communists.

Meanwhile, the regime continues feeding enough credit to the SOEs to keep them alive; conditioning the credit on hoped-for restructuring, but not so much credit that inflation is unleashed. Inflation has been a continuing problem, causing the regime to punctuate the growth of the last two decades with binges of harsh austerity. What many in the West view as a struggle between hard and soft-liners, or between a "Maoist" left and a "market socialist" right, is really a reflection of managing a business cycle with "Chinese characteristics." This is a risky business for the regime. The price controls of the late 1980s certainly tamed an inflation rate that reached 50 percent in 1988 , but that austerity was considered a key factor in triggering the 1989 social revolt centered in Beijing's Tiananmen Square. ${ }^{35}$ The protests received widespread popular support with marches of a million workers or more in several major cities. The regime could only kill the movement by relying on the brutal efficiency of crack troops from the People's Liberation Army. After that event controlling wages was much less of a problem for several years. ${ }^{36}$

Thus, "muddling through" may not be sufficient. The credit that sustains the growth process must come from somewhere. The free trade zones on the Chinese coast are fed by foreign direct investment. But the

32 Stephen F. Diamond, The PetroChina Syndrome: Regulating Capital Markets in the Anti-Globalization Era, 29 J. CoRP. L. 101 (2003).

33 STUDWELL, supra note 20, at 215.

34 50,000 Daqing Oilfield Workers Organise Independent Trade Union, CHINA LAB. Bull., Mar. 6, 2002; Mass Paramilitary Deployment Quells Daqing Demonstrations, China LaB. Bull., Mar. 26, 2002.

35 KHAN \& Riskin, supra note 24, at 107.

36 StUdwell, supra note 20 , at 51 (noting that a "particularly perverse. . . effect of the aftermath of the Tienanmen killings was that the government was able to see through its austerity programme. . without a murmur of dissent. The population was too terrified to object. ... Urban wages were held down and the urban unemployment rate reached its highest level since the start of the decade."). 
SOEs and the domestic private sector rely on the recycling of the huge savings of ordinary Chinese people. Since the banking system is stateowned and, in theory, the renminbi is not convertible into foreign currencies, Chinese workers, peasants and small businesses are forced to finance the continued capital accumulation drive of the Communist regime. The whole game depends on the regime's continuing top-down control of that financial system. Thus, promises of convertibility of the currency as early as 1993 are now put off well into the future. ${ }^{37}$

Of course, if the renminbi were freely tradable on the world markets and if ordinary Chinese savers could freely hold their savings in foreign banks or invest them in the equities of European or American companies as their counterparts do in the West and much of Asia, there would most likely be a massive "run on the bank" as the value of Chinese assets would be forced to come into line with global values. The pressure on domestic values is so great that Studwell argues that even without convertibility or an opening of the financial sector a bank run is still a possibility: "[e]verything comes down to psychology. . . the psychology of the ordinary Chinese people," he notes ${ }^{38}$ From this vantage point, events like the 1989 Tiananmen revolt take on new meaning. China may be in the grips of an investment bubble that, once it bursts, will cause a social and economic crisis that dwarfs that which afflicted most of Asia in the late 1990s. In the case of China, the "hot money" that sparked the Asian financial crisis is actually represented by the domestic savings of ordinary Chinese, fueled by the bulging domestic reserves linked to Chinese exports. A "flood of credit [in the 1990s] allowed an over-investment binge that caused the ratio of private investment to personal consumption to peak at 83 percent in 1993 and to remain above 70 percent thereafter." ${ }^{39}$ The regime's credibility, and therefore its power, depends on maintaining the credibility of its economic policy. It is not just that the regime fears a Solidarity-like protest movement rising up in reaction to political repression or unemployment; it also fears a tearing away of the veil that covers up the country's financial fragility. This could, in turn, cause the population to lose their faith in the regime and, in turn, trigger a massive political upheaval.

What are the escape routes for the regime? A massive debt-forequity swap is one. Since the debts the state has accumulated using domestic savings must eventually be repaid and in the meantime the state must pay interest, the debts can get very expensive. The stateowned banks now hold massive amounts in non-performing loans made to the SOEs and the TVEs. On top of that, the government has huge

37 StUdwell, supra note 20 , at 211-212.

38 Id. at 214.

39 Duncan, supra note 9, at 159. 
under-funded pension liabilities. When these massive liabilities are added together, Studwell estimates a debt-to-equity ratio of nearly 500 percent for the state sector-outstripping even South Korea on the verge of its economic collapse in $1997 .^{40}$ So by creating stock markets, the regime has tried to encourage Chinese savers to invest instead in equity issued by these same state companies. The regime even dreams of large mutual funds rescuing them from the pension trap they face, hoping they can convince Chinese workers to trade the "iron" rice bowl guarantees of an earlier era for the volatile world of publicly-traded equities. But equity holders expect capital gains over time and hope that inside managers will pay out regular dividends, and neither is legally mandated. And in China, senior corporate insiders, for the most part still members of the ruling Communist Party, have the additional advantage that they need not fear the disciplinary effect of a potential takeover by competitors or financial players since there is, as of yet, no competitive market for corporate control in China ${ }^{41}$ This shift to equity finance explains the stock market mania that hit China in the 1990s. The regime engaged, it appears, in a massive "pump and dump" scheme touting share ownership in companies that by any stretch of the imagination were actually worthless. In the first half of 1992 the Shanghai stock market index registered an unsustainable gain of 1200 percent. ${ }^{42}$

A second strategy has been to turn to foreign stock markets, first in Hong Kong, but more recently to the London and New York Stock Exchanges. There Chinese companies have been notably less successful. The pump-and-dump has not fooled quite as many investors. Where Chinese companies trade their stock both at home and on the Hong Kong exchange, the shares sold in Hong Kong trade at a substantial discount, as much as 85 percent, giving the outside world some idea of the discount factor that one might have to apply to the entire Chinese economy if its assets were freely tradable. ${ }^{43}$ Finally, the regime has encouraged the establishment of foreign investment in the so-called Special Economic Zones. But even the explosive growth of the Zones makes a relatively small dent in this massive country. More importantly, their potential future growth is limited. Most of these plants are only final assembly points in a global assembly line so that the value added by Chinese workers is a small percentage of top-line revenue. The sector shipped $\$ 150$ billion worth of goods in 2000 , but less than 25 percent of that was value added in the free trade areas in China. ${ }^{44}$ The state sector cannot compete yet in quality and reliability with the foreign suppliers

\footnotetext{
40 StUdWell, supra note 20, at 206.

41 Stephen F. Diamond, The PetroChina Syndrome, supra note 32, at 127.

42 Id. at 65.

43 Id. at 213.

44 Id. at 226.
} 
that feed parts into the assembly plants. In addition, the companies are heavily dependent on the infrastructure provided by coastal proximity to Hong Kong and Taiwan. Interestingly, as Khan and Riskin note, despite what free trade theory might predict, the industrialization in this and the TVE sectors "so far. . . has been quite employment-hostile" with increases in employment declining "drastically" even as output spurted ahead. $^{45}$

The social and political effects of this process are equally striking. As a result of this reform process there are estimates that as many as 20 million people a year are leaving the rural areas of China for the cities in search of work. ${ }^{46}$ To put this in perspective, a single year's inflow of new urban workers in China is equivalent to the entire manufacturing employment base of the United States. In fact, because of the recent downturn in the U.S. economy some 2 million jobs have been lost and manufacturing employment in the U.S. has now dropped to a twentyyear low of 16 million jobs. This has now made the U.S.-China trade balance a politically sensitive issue inside the United States. ${ }^{47}$ China's trade surplus with the United States is now the world's largest, reaching $\$ 83$ billion in 2001, while the balance with Mexico was in surplus only to the tune of $\$ 30$ billion. ${ }^{48}$ Even Japan, America's most feared competitor in the 1980 s, had a surplus of only $\$ 69$ billion that year. ${ }^{49}$ This has led to pressure by the U.S. government on China to revalue its currency, currently pegged to the dollar at a rate of roughly 8 to 1 , thus making U.S. exports relatively more expensive. ${ }^{50}$ Meanwhile, as discussed below, domestically China is experiencing an unprecedented wave of worker unrest. Thus, the reform process is creating internal and external imbalances that are increasingly the stimulus for domestic social conflict and global tension.

45 KHAN \& Riskin, supra note 24, at 152-53.

46 Karby Leggett, The Outlook: Under Pressure, China Blesses Private Sector, WALl ST. J., Mar. 13, 2000, at A1 ("20 million new job seekers enter the labor market every year); Andy Xie, China: The Virtuous Cycle Continues, Morgan Stanley Global ECON. F., Mar. 6, 2001 ("China's biggest challenge is to create 20 million jobs a year to absorb the entire labor surplus over two decades").

47 Neil King, Trade With China is Heating Up As a Business and Political Issue, WALl St. J., Jul. 30, 2003, at A1; David Barboza, Textile Industry Seeks Trade Limits on Chinese, N.Y. Times, Jul. 25, 2003, at C1; Karby Leggett \& Peter Wonacott, Surge in Exports From China Gives a Jolt to Global Industry, WALL ST. J., Oct. 10, 2002, at A1.

48 Duncan, supra note 9, at 201.

49 Id.

50 Chen Zhao, The Fed is in a dangerous game with China, Fin. TIMEs (London, England), Jul. 30, 2003, at 11; David DeRosa, Everybody Is Prodding China to Revalue the Yuan, BLOOMBERG, Jul. 11, 2003. 


\section{Chinese Trade Unionism}

A central feature of China's approach to economic policy is to maintain tight control over its workforce even as it opens up the economy. Thus the country's policy towards trade unionism is crucial to understanding the relationship of China to the world economy today. As is widely accepted in political theory and history, trade unions provide a counterweight to the power of government and business interests in a modern industrial society. The aggressive spread of neo-liberal policies through globalization has undermined the ability of unions to play this role in the post-Cold War world. But the need for trade unions has only increased. The political impact of trade unions is widely recognized. The effort to organize a union requires certain political liberties, such as free speech, the right of assembly and the right to have grievances redressed. These broader political liberties run parallel to core labor standards like the right to join the union of one's own choice and the rights to organize, to bargain, and, if necessary, to strike. A country with a strong union movement is also likely, therefore, to be a country with a vibrant democracy and respect for the rule of law.

These rights are still largely absent in China and this is reflected in the status of the labor movement there. The ACFTU is simply a creature of the Chinese state and the Communist Party. It is obligated by its own rules and law to act as a transmission belt for party and state policy. As labor unrest has spread across China in the last few years, the ACFTU has sat on the sidelines, emerging on occasion only to condemn these rank-and-file efforts to secure jobs, pensions and other basic economic benefits. In the wake of the mass protests in the spring of 2002 by workers in the metal industry of Liaoyang that led to the imprisonment of Xiao Yunliang and Yao Fuxin, ${ }^{51}$ the ACFTU publicly condemned the two worker leaders at the annual conference of the ILO in Geneva for "illegally demonstrating" and charging them with having "burned cars and destroying public property" although the latter charge was never brought forward in court. ${ }^{52}$ Later, in a reply to the ILO's own investigation of the Liaoyang events, the Chinese government accused the leaders of "terrorism and sabotage," never brought against the activists in the eventual court case discussed above. $^{54}$ During the same time period workers in the oil industry in Daqing in northern China organized demonstrations against cuts in severance benefits. Their actions were condemned as "unacceptable and

51 See supra text accompanying notes 1-3.

52 Liaoyang Workers' Struggle, supra note 1, at 11.

53 Id.

54 See Criminal Verdict, supra note 1 , at 71 . 
illegal" by the ACFTU..$^{55}$ This is a pattern that is all too familiar to students of societies in transition from Stalinism to modern capitalism. There is little hope that China will avoid this pattern. And thus the international labor movement has generally given its support to efforts to form genuine, independent unions in China as part of the support for the development of the rule of law and respect for human rights. ${ }^{56}$

Independent trade unions are outlawed in China. ${ }^{57}$ The ACFTU maintains what the International Confederation of Free Trade Unions ("ICFTU"), the leading global labor umbrella organization, calls a "trade union monopoly." $"$ The right to strike does not exist. ${ }^{59}$ An effort to establish a Workers Autonomous Federation (WAF) as part of the wider Democracy Movement of 1989 was met with particularly harsh repression. Many affiliates of that Federation are still in prison or labor camps. Amnesty International details numerous ongoing abuses of workers for their organizing and other activity. ${ }^{60}$ Arrests and arbitrary detentions were made throughout 1999 as labor unrest increased due to the worsening economic situation. Here are some of the examples they report:

Li Qingxi, a laid-off worker from the Datong coalmine in Shanxi province, was arrested in January when he posted publicly a statement calling for independent trade unions. He was sentenced in March without charge or trial to one year of "re-education through labor," reportedly to be served "at home." Zhang Shanuang, a labor rights activist from Hunan province, was detained in July after trying to set up a group to help laid-off workers. He was sentenced in December to 10 years' imprisonment, accused of having "illegally provided information to overseas hostile organizations and individuals," reportedly for speaking about farmers' protests in his province in a Radio Free Asia interview. ${ }^{61}$

The widely respected China Labour Bulletin, based in Hong Kong, confirms that the process of "economic restructuring has led to huge pressures on the Chinese labour market. . many workers laid off from

55 Press Release, China LAB. Bull., Mar. 6, 2002 (on file with author).

56 Int'l Confederation of Free Trade Unions Executive Bd., ICFTU China Policy (November 27-29, 2002) (on file with author) ("noting that the ACFTU is not an independent trade union organization and, therefore, cannot be regarded as an authentic voice of Chinese workers").

57 Int'l Confederation of Free Trade Unions, Annual Survey of Violations of Trade Union Rights (2003) [hereinafter ICFTU Survey].

58 Id.

59 See discussion infra at notes 84-92.

60 Amnesty Int'L, Report 1999 (1999). Amnesty INT'L, People's Republic of China: Labour unrest and the right to freedom of association and expression: "Workers want to eat - Workers want a job," AI INDEX: ASA 17/015/2002 (Apr. 2002).

61 Amnesty INT'L, Report 1999 (1999). 
SOEs have expressed dissatisfaction with the long working hours, shortterm contracts and miserly benefits that more than not await them in the private sector." ${ }^{62}$ Linked to this dissatisfaction is a rise in labor disputes, despite the frightening risk that such voicing of grievances to official bodies entails. Even the state-controlled Labor Disputes and Arbitration Committees reported a 58 percent increase in cases heard in the first six months of 1999. Of course, the vast majority of such disputes are reported only as "solved" with few details available on the facts. There are serious procedural obstacles to bringing such disputes to the dispute resolution bodies, so it is unknown how many on the job grievances go unreported.$^{63}$ In fact, the worst fears of critics of the PetroChina IPO and restructuring process came true in the spring of 2002 when massive demonstrations by laid-off workers took place in the Daqing oilfields owned by CNPC and PetroChina. ${ }^{64}$ These were soon followed by large protests by unemployed workers in several parts of China, including an unusual demonstration by workers in Beijing itself. Arrests of protest leaders such as the fathers of Yao Dan and Xiao Yu were paired with modest economic concessions by the regime thus ending this particular wave of unrest. ${ }^{65}$ However, one sociologist calls these demonstrations evidence of a "labor insurgency" underway in China. ${ }^{66}$

All of China's industrial workers are members of the only "trade union" body allowed to exist - the ACFTU. The ACFTU is a constituent body of the Chinese State and thus is controlled by Communist Party cadre. As in the former Soviet Union and its Eastern European satellites, this is a "trade union" in name only. It is, in fact, in the Chinese regime's own words, "a mass organization of the working class" and it serves as a transmission belt for the party and state leadership. The Communist Party appoints all of its officials. As the ACFTU itself stated in 1990: "the administration of union cadres by the Party is an unchangeable principle. The ACFTU should work together with the Organization Department of the Central Committee of the Chinese Communist Party in laying down regulations concerning cadre management and in monitoring the nomination, investigation, election, approval and allocation of union leaders." The same document goes on to state that:

62 Feature: Unemployment, 50 China LAB. Bull. (Sept.-Oct. 1999). 1999).

63 See Workers' Forum: The Struggle Continues, 51 China Lab. Bull. (Nov.-Dec.

64 Radio Broadcast Transcript, Daqing Oilfield Workers' Struggle, CHina LAB. Bull., Mar. 6, 2002.

65 Press Release, Amnesty Int'l, "Subversion" Charges Must Not Be Used to Imprison Rights Activists (Jan. 14, 2003).

66 Ching Kwan Lee, From the Specter of Mao to the Spirit of the Law: Labor Insurgency in China, 31 THEORY \& SOC'Y 189 (2002) [hereinafter Specter of Mao]. 
trade unions must resolutely oppose any organization or individual expressing political views countering those of the Party. . . On discovering the formation of workers' organizations which oppose the Four Cardinal Principles ${ }^{67}$ and endanger the national regime, the trade union must immediately report to same-level party committees and senior-level unions, and must resolutely expose and dissolve them. When necessary, the union should demand the dissolution of such organizations by the government in accordance with the law. Concerning organizations initiated by workers out of their specific economic interests, the union should advise them to dissolve and terminate their activities through persuasion and counseling. ${ }^{68}$

Thus, the ACFTU serves as the "eyes and ears" of the state inside every workplace. Far from supporting democratic and free trade unionism, the ACFTU's central purpose is to carry out State and Party directives and to do everything it can to insure that all workers fall into line as well.

It is no surprise to find out, therefore, that the ACFTU is viewed by the state as a vehicle for encouraging worker support for the very economic reform process that is devastating the social conditions of tens of millions of workers. Dan Gallin, then General Secretary of the International Union of Food, Agricultural, Hotel, Restaurant, Catering, Tobacco and Allied Workers Associations ("IUF"), noted after a mission to Hong Kong in December, 1997, that earlier that month at a meeting of the Executive Committee of the All-China Federation of Trade Unions Hu Jintao (then a senior member of the Chinese Communist Party and now President of China) urged trade union leaders to "arouse workers' enthusiasm about reforms in [the state-owned enterprises], especially about turning losses into profits and to complete the tasks set forth during the recent 15 th party congress." $\mathrm{Hu}$ Jintao added that trade unions should "encourage workers to contribute to the development of new products and technological improvements," that they should provide more job opportunities and professional training for laid-off workers, and encourage them to change their old ideas and find new jobs themselves." ${ }^{\circ 9}$ Those who do not conform to the new economic order are subject to ACFTU "mobilizations." The Chinese political police (Public

67 The Four Cardinal Principles include: 1) To keep to the socialist road; 2) To uphold the people's democratic dictatorship; 3) To uphold the leadership by the Communist Party; and 4) To uphold Marxism-Leninism and Mao Zedong Thought. See Constitution of the Communist Party of China (CPC) amended and adopted at the 16th CPC National Congress on Nov. 14, 2002 (on file with author).

68 INT'L UNION OF FOODWORKERS, REP. OF THE INT'L UNION OF FOODWORKERS on Mission to China 18 (1997), available at http://www.global-labour.org/china.htm [hereinafter IUF Mission To CHINA].

69 Id. at 4. 
Security Bureau or "PSB") have issued "guidelines" that state that "the union[s] must . . . co-ordinate with the PSB, organize 'public order and prevention teams' to protect the internal security and order of the enterprises, as well as social order. Staff and workers should be mobilized to struggle against all forms of criminal and illegal behavior. The union must also assist the relevant authorities to deal adequately with the education and employment of dismissed employees, workers who have committed errors and those have completed sentences and been released." ${ }^{\prime 70}$ This kind of directive can only be characterized as chilling.

Far from encouraging progressive change, as China has integrated itself into the world economy, its approach to trade unions has remained rigidly closed. A 2001 revision to the Trade Union Law, last revised in 1992, only confirmed this. A new version of Article 4 of the Law, for example, confirms the obligation of the ACFTU to: ". . .take economic construction as the centre, adhere to the socialist road, uphold the people's democratic dictatorship, abide by the leadership of the Chinese Communist Party, adhere to Marxism-Leninism Mao Zedong Thought and Deng Xiaoping Theory." 11 The Law also mandates that the ACFTU role in the face of a strike is to ". . .assist the enterprise or institution in making proper preparations for resuming work and restoring work order as soon as possible." ${ }^{22}$ The China Labour Bulletin concludes that such provisions:

reaffirm. . . the ACFTU's subordinate relationship to both the government and the party at three levels: the union must abide by the Party's guiding principles; the union must subordinate its organization to the Party machinery; and the union must perform the function of carrying out the wishes of the Party in its intervention in labour disputes at local or enterprise level. ${ }^{73}$

In addition to the dramatic human rights picture and the suppression of basic trade union freedoms, the general situation of workers presents additional problems. Unemployment and forced migration have already been mentioned. Other problems include the widespread use of underemployment, short-term work, and contract labor, the continued control of labor mobility by the state and massive violations of basic health and safety precautions. Official statistics report nearly seven million unemployed urban workers, but the China Labour Bulletin

70 Id.

71 Cited in Analysis of the New Trade Union Law, China Lab. Bull., Feb. 28, 2002.

72 Id.

73 Id. 
estimates that the total is closer to 21 million. $^{74}$ And even official statistics admit to 30 million "more than needed" workers in the urban areas. These are now supplemented by some 80 to 100 million "floating people" who have left their villages looking for work in other areas of the country. ${ }^{75}$

Despite the need for a massive shift in employment to new entities, the state fears that uncontrolled mobility could open the door to organized opposition to the regime. Thus, it has largely kept in place a decades-old system of labor registration-the hukou system. ${ }^{76}$ Under hukou every Chinese citizen is required to "have a registration with the hukou authority or hukou police at birth." In theory no Chinese may work or live outside of the area where they were registered at birth. To accommodate some economic pressures, the regime has instituted a system for providing workers with temporary residence permits. Punishment of both employers and employees is meted out if workers are hired without a permit. ${ }^{n}$

Nonetheless, in the face of the officially-backed repression of genuine trade unionism, workers have consistently attempted to organize independent movements throughout the history of post-1949 Communist China $^{78}$ Far from passively accepting the ideological claim of the regime to be a "workers' state," Chinese workers have defied the mythology of the regime in successive waves of unrest. Interestingly, in the first few years of Communist rule the newly-established ACFTU was independent and militant-somewhat like the trade unions in the first few years of Castro's rule. But as in Cuba the state soon stepped in and deposed the independent ACFTU leaders, turning the organization into a party-run transmission belt organization after the classic Stalinist model. Worker restiveness did not take long to reemerge, however, with a strike wave in 1956-57 that was apparently directly influenced by the Hungarian uprising of that same year. Repression followed but so did periodic

74 The official figures can be found in Fei-Ling Wang, Labor Issues and Foreign Direct Investment in the PRC, in Advances in ChINese Industrial Studies - The Managerial Process and Impact of Foreign Investment in Greater China 177 (C. Jayachandran et al. eds., 1999). The China Labour Bulletin estimates are described in their study Feature: Unemployment, supra note 62.

75 See Fei-Ling Wang, Id. at 40.

76 See id. at 178.

77 On the hukou system and the contemporary Chinese labor market, see Fei-Ling Wang, Floaters, moonlighters, and the underemployed: $A$ national labor market with Chinese characteristics, 7 J. CONTEMPORARY CHINA 459 (1998); see also Section 301 Petition, AFL-CIO, Mar. 16, 2004, available at http://www.aflcio.org/issuespolitics/ globaleconomy/upload/china_petition.pdf (last visited Apr. 13, 2004).

78 The following summary of independent worker activity is based on Worker Passivity in China: A Maoist Myth, China LAB. Bull., Nov. 2003 available at http:// iso.china-labour.org.hk/iso/ [hereinafter Worker Passivity]. 
worker unrest, particularly during the Cultural Revolution and in the wake of the death of Chou En Lai in the 1970s. In each case, the state cracked down. In the early 1980s the Democracy Wall movement emerged and included specific references to Poland's Solidarity. Sociologist Ching Kwan Lee notes that "[t]he ascendance of the Polish Solidarity Movement emboldened Chinese workers. . . to take action." 79

As economic reform under Deng gathered steam, worker unrest resurfaced. The spring 1989 movement led to the most important period of independent worker organizing in recent years. The activists of the newly established Beijing WAF, which sparked numerous WAFs all over the country, initially met with some hostility from the student demonstrators, who restricted the workers' presence in Tiananmen to a corner of the square. ${ }^{80}$ The China Labour Bulletin describes what happened:

As the numbers of students directly participating in the Democracy Movement slowly began to dwindle, the WAFs became stronger. Links between WAFs all over China were being forged and some activists traveled to Beijing for discussions. Correspondingly the position of the ACFTU hardened towards the WAFs and on June 2, 1989 the official Workers Daily called for the banning of the WAFs as illegal organisations. The call was perhaps premature. Two days later government troops fought their way into the Square and made straight for the BWAF tents. In the repression that followed, thousands of workers suspected of taking part in WAF organisations were rounded up and shot or sent to prison. ${ }^{81}$

According to Ching Kwan Lee, "in May and June 1989, workers in Beijing, Shanghai and other cities left the confines of factory gates and their collective action took the forms of public protests, independent unionism and political mobilization." ${ }^{82}$ She notes that workers detained in the 1989 crackdown "receiv[ed] the heaviest [prison] sentences." ${ }^{83}$ Thus, the burgeoning workers' movement was central to the dynamic of the 1989 events. Sporadic efforts to organize independent unions and even political parties continued through the 1990s, but with leaders almost invariably ending up in prison.

79 Ching Kwan Lee, Pathways of Labor Insurgency, in CHINESE SOCIETY: Change, Conflict and Resistance 48 (Elizabeth J. Perry and Mark Selden eds., 2000) [hereinafter Labor Insurgency].

80 Id. at 56, Lee notes the "Beijing students' disdainful stance towards workers' participation in the Tiananmen protests." Eventually, though, several students became active leaders of the WAF movement.

81 Worker Passivity, supra note 78.

82 Labor Insurgency, supra note 79, at 49.

83 Id. 
In the late 1990s, however, widespread unrest began to reemerge among workers responding to massive shutdowns of state industries. In many instances these companies were being restructured with the crown jewels of what remained being appropriated by party insiders. Most of these protests were small (a few dozen or a few hundred at most). But there have been some important exceptions. Chinese coal miners face some of the most horrendous working conditions to be found in China and have been heavily victimized by mine closures. The Labour Bulletin report noted that "in 1999, the PLA was employed to put down a threeday protest by 20,000 miners in Liaoning province where miners were reported to have taken over a town." ${ }^{44}$ There were also steady reports in the same time period of other "large-scale clashes between miners and armed police over closures and wage arrears." 85

In the spring of 2002, as noted earlier, this unrest hit the famed Daqing oil fields, where PetroChina had begun a massive downsizing project after its IPO in $2000{ }^{86}$ Tens of thousands of workers took to the streets there to protest an attempt by the regime to cut back on promised severance benefits. The part the ACFTU played in these events demonstrates its true role. Its representatives called the Daqing oil workers protest "illegal and unacceptable" because according to the ACFTU constitution new unions could only be established by existing unions from above and not by workers themselves. It said that it had "no role to play" in the battle by these workers for their pensions because of official instructions they had received from the Communist Party committee in the oil industry that their role was only to "understand" the situation, not to advocate the workers' interests. In the words of the ACFTU representative in Daqing: "[u]nder the union system in China, the organizational relation of a union is defined by the party. ... [T] he trade union has a subordinate relationship to the Party, and a trade union must be set up according to an organizational structure of leadership that runs from top to bottom." Tiananmen Square veteran union activist Han Dongfang issued a statement condemning the role played by the ACFTU in the Daqing protest and urged the ACFTU to recognize the right of the workers to organize their own union. For such efforts in the past Han Dongfang has been condemned at the ILO's

\footnotetext{
84 Worker Passivity, supra note 78.

85 Id.

86 When the huge Daqing oil reserves were exploited during the reign of Chairman Mao, the workers of Daqing were widely hailed as heroes. The oil workers were the basis of a classic Stalinist labor emulation campaign as Mao told China to "learn from Daqing" and rewarded so-called "Iron Man" Wang Jinxi for his prodigious productivity. This approach to labor discipline originated in the Soviet Union under the term Stakhanovism. John Gittings, Strikes Convulse China's OilRich Heartlands, The Guardian, Mar. 21, 2002 at 20.
} 
annual conference by China's representatives as a "criminal." Ching Kwan Lee's research confirms the "ambiguous and conciliatory role played by the local ACFTU." ${ }^{87}$ Even in the foreign investor-controlled Special Economic Zones, where some western union advocates of a rapprochement with the ACFTU feel it could act to genuinely defend worker interests, "[u]nion officials were. . helpless in defending workers during strikes in foreign-owned enterprises when public security personnel were often called into the [company] compounds by management to intimidate strikers." ${ }^{188}$ Indeed, Lee notes that the widespread reports of high-density unionization rates in the foreign enterprise sector largely reflect "ACFTU-approved unions [that] were led and staffed by management personnel who were mainly responsible for collecting union fees, organizing birthday parties and recreational events. These union leaders were also salaried shop floor supervisors or section heads in the factory administration." ${ }^{\prime 9}$

A central theme of the state's behavior in the current period is to try to placate pure economic demands (over issues such as severance pay) while clamping down when the actions move to the formation of some kind of independent workers' organization. Since repression of potential unrest is so crucial, it is no surprise that until very recently the head of the ACFTU, Wei Jianxing, was the same government official who as a member of the Standing Committee of the Chinese Communist Party's seven member elite Politburo had been in charge of the regime's anticrime "Strike Hard" campaign. This campaign was aimed at suppressing alleged corruption and led to widespread arrests and use of the death penalty against thousands of party officials and businessmen..$^{90}$ Wei's approach to independent unions could not be more clear. He views them as "an attempt to 'westernize' and 'pluralize' us" by "our enemies, at home and abroad" who "seek to overturn the leadership of the Party and subvert the socialist system." " The Labour Bulletin concluded its report by noting that:

87 Labor Insurgency, supra note 79, at 51.

88 Id.

89 Id.

90 Press Release, Amnesty Int'l, China: One Thousand Executed in Strike Hard Campaign Against Crime (July 2, 1996), available at http://www.amnesty.it/news/1996/ 31707196.htm (condemning campaign as "state killing on a massive scale" and "widespread arbitrary violation of the most basic right to life"). A revival of this approach is underway now in China. China Punishes 12,000 Criminals Involved in Organized Crimes, People's DaIly (Beijing), March 11, 2002.

91 Wei, Jianxing, Conscientiously Implement the Spirit of the Fifth Plenary Session of the 15th Central Committee and Speed Up the Organising and Establishing of Trade Unions in New Enterprises, Address at Work Meeting on Organising and Establishing Trade Unions in New Enterprises (Nov. 12, 2000), in Trini Leung, ACFTU and Union Organizing, ChINa LAB. Bull., Apr. 2002. 
Where the state has definitely not adopted a "soft" approach has been when labour organisers have attempted to take advantage of the situation and set up labour organisations. These are rarely actually in workplaces. Unemployment has been such a major feature of recent economic trends that many of the angry workers involved are protesting because they have no workplaces to go to. The case of Hunan-based independent trade unionist Zhang Shanguang is an example of how brutal the regime can be in dealing with labour organisers. While Zhang's association for laid off workers was largely apolitical, the attempt to register the organisation legally-on the back of China's signing of the International Covenant on Economic Social and Cultural Rights and the International Covenant on Civil and Political Rights-was a profoundly political act. Zhang Shanguang was locked up for trying to organise the Shu Pu County Association for the Rights of Laid Off Workers. Zhang has a history of labour organising and in 1989 was sentenced for his involvement in the Hunan Workers Autonomous Federation (HWAF). On his release, he was blacklisted by employers and denied work. In the more recent arrest, the police handed Zhang's wife an official "Notice of Detention," which stated that Zhang was a threat to national security and was being detained under Article 61 of the Criminal Procedures Bill. After a secret hearing lasting two hours, he was sentenced to 10 years. ${ }^{92}$

As in most authoritarian regimes the real fear is of independent organization. A real trade union would rob the official state labor organization of its legitimacy and thus would open the door to deeper political change.

A real trade union movement in China could also have an important economic, as well as political, effect. Economists have noted three major macro-level imbalances in China today: limited domestic demand, deflationary pressures and regional unevenness in the pattern of development. A trade union movement would, through genuine adversarial bargaining, force the regime to be more transparent and balanced in its economic decision-making. Wages would increase, thus stimulating domestic demand and price levels. This could lead to a more balanced domestic development pattern but also weaken global tensions with countries that already recognize trade unions. Financial analyst Richard Duncan, for example, has recently called for the establishment of a global minimum wage for workers in export industries as a means to restore balance to the global economy, particularly because of the impact of cheap labor in China: ${ }^{93}$

92 Worker Passivity, supra note 78.

93 Duncan, supra note 9, at 233. 
Increasing wages in the developing world would augment global aggregate demand. It would succeed in putting more money in people's pockets, something that traditional monetary policy is incapable of doing in [the] post-bubble environment [the world is now experiencing.] . . . As consumption expanded in the newly industrializing countries, so would demand for imported goods, an important development that would help restore balanced trade in the world. ${ }^{94}$

But to make this argument about the impact of a genuine labor movement in China is to point to a post-Communist China that is no longer wed to the "race to the bottom" export-led model of growth and that is precisely why the regime must resist in every conceivable forum such a movement.

\section{The International Legal Arena}

This concern for the wider political and economic impact of a real trade union movement leads to the third area of concern: the role that international legal institutions are playing in the process. Unfortunately, rather than serve as a reminder of the importance of balance, equity and accountability in a major socio-economic experiment like that occurring in China today, these institutions are actually pushing the regime forward. There are many explicit examples of this process when, for example, the World Bank provides technical advice on the downsizing and privatization of key industries. But just as problematic are those steps taken at the WTO and the ILO that undermine the ability of independent unions to emerge as counterweights to the muted form of shock therapy now underway in China. The story of the granting of Permanent Normal Trade Relations with China by the United States is relatively well-known. ${ }^{95}$ In doing so, the United States gave up one of its most important levers of influence over the progress of labor rights and human rights in China. Less well known, however, is the groundwork that was laid for China's entry into the global economy at the ILO and the WTO.

One of the important achievements of the international labor rights movement over the last decade has been its promotion of the concept of "core labor standards" that comprise those rights seen as essential to the development of an effective trade union movement. This campaign has given labor activists in many arenas the ability to push for a coherent global agenda. Recognition of the core standards has now been made in a variety of environments, though the precise content of the standards

94 Duncan, supra note 9, at 238.

95 See Bridging the Divide, supra note 18. 
varies slightly across institutional settings. In 1998 the ILO's International Labour Conference, its central body made up of all its member states together with worker and employer representatives, issued a Declaration on Fundamental Principles and Rights at Work. The Declaration stated that there are four fundamental rights which its members had "an obligation. . . to respect, to promote and to realize," including: "freedom of association and the effective recognition of the right to collective bargaining; the elimination of all forms of forced or compulsory labour; the effective abolition of child labour; and the elimination of discrimination in respect of employment and occupation." ${ }^{\prime 96}$ Respect for these same principles is now found in the emerging markets investment strategy of the California Public Employees Retirement System ("CalPERS"), the world's most important institutional investor, and in the Generalized System of Preferences in the global trade regime. ${ }^{97}$ Even the WTO recognized its members' obligation to foster respect for Core Labor Standards at its Ministerial Conference in Singapore in $1996{ }^{98}$

But there is a catch. The ILO and the WTO each carved out an exception to the core standards that flatly contradicts the central principle of international labor solidarity that has guided the international labor rights movement since the founding of the ILO in 1919. Paragraph 5 of the ILO's Fundamental Declaration states that:

The International Labour Conference. . . Stresses that labour standards should not be used for protectionist trade purposes, and that nothing in this Declaration and its follow-up shall be invoked or otherwise used for such purposes; in addition, the comparative advantage of any country should in no way be called into question by this Declaration and its follow-up.

96 ILO, Declaration on Fundamental Principles and Rights at Work, 86th Session, Geneva (June, 1998) available at http://www.ilo.org/public/english/standards/decl/ declaration/text/tindex.htm (last modified Dec. 8, 2000). The fundamental rights are made up by eight fundamental ILO Conventions, including: 1) Freedom of Association and Protection of the Right to Organize Convention, 1948 (No. 87); 2) Right to Organize and Collective Bargaining Convention, 1949 (No. 98); 3) Forced Labour Convention, 1930 (No. 29); 4) Abolition of Forced Labour Convention, 1957 (No. 105); 5) Discrimination (Employment and Occupation) Convention, 1958 (No. 111); 6) Equal Remuneration Convention, 1951 (No. 100); 7) Minimum Age Convention, 1973 (No. 138); 8) Worst Forms of Child Labour Convention, 1999 (No. 182). Int'l Labour Organisation, Fundamental ILO Conventions, available at http://www.ilo.org/public/english/standards/norm/whatare/fundam/index.htm (last modified Oct. 20, 2000).

97 Press Release, CalPERS, CalPERS Board Takes Action on Investment and Other Measures, Nov. 15, 2000, available at http://www.calpers.ca.gov/whatsnew/press/ 2000/1115a.htm.

98 Singapore Ministerial Declaration, Dec. 13, 1996, P4, 36 I.L.M. 218, 221. 
But labor standards are promulgated precisely because they are protectionist: protective of the relatively advanced conditions won by workers in economies with established trade unions. Many of these protections were won only after bitter battle with employers and governments alike. Thus, the Preamble to the ILO's Constitution, drafted at the ILO's opening conference in 1919, states that "the failure of any nation to adopt humane conditions of labour is an obstacle in the way of other nations which desire to improve the conditions in their own countries." 99 This concept of labor standards as a protective floor beneath which the world should not fall was reaffirmed at the Philadelphia Convention that restarted the ILO in the post-World War II world. Thus, it was precisely the need to avoid the allegedly non-existent "race to the bottom" in global labor standards that explains the very origin of the ILO.

As former National Labor Relations Board Chair and leading labor law scholar William B. Gould IV has pointed out, this principle of international labor solidarity has a firm basis in domestic U.S. law.

The idea of unfair competition. . . is also reflected in portions of the National Labor Relations Act's own preamble, enacted to promote freedom of association and collective bargaining in the Untied States shortly after the United States joined the ILO. . . . Interestingly, in enacting the NLRA, Congress announced that a primary purpose of this policy was to remove the downward pressure on wages that a failure to protect collective bargaining produces. ${ }^{100}$

It was no surprise, therefore, that the proposed carve-out language that aimed to protect the cheap labor export model of growth found in developing countries was the cause of bitter debate in the ILO during its 1998 Conference. The United States representative (from the Clinton Administration) and the delegates representing the trade union movement bitterly opposed the language, while many developing countries, including China, pushed hard for it. If the leading United Nations agency responsible for promoting global labor standards was unable, or unwilling, to stand up to the pressures of globalizationtossing aside an 80-year-old core principle in favor of cheap labor and the return of sweatshops-is it any surprise that the international labor movement finds itself in such a challenging position?

99 Treaty of Versailles, June 28,1919 , pt. XIII $\S$ I headnote, 225 Consol. T.S. 188.

100 Gould, supra note 16, at 720. Oddly, Professor Gould seems to accept the notion that Congress had it right about the impact of a race to the bottom on interstate commerce in 1935 when it passed the NLRA but that the international labor movement has now got it wrong in suggesting that the weight of hundreds of millions of workers barely paid a subsistence wage are no longer an obstacle to the progressive development of international commerce. 
As if to add insult to injury, in the summer of 2002, the ILO elevated the representative of China's ACFTU to an alternate seat on the ILO's Governing Body. ${ }^{101}$ Apparently some ILO delegates attempted to justify the vote, which meant that Israel's Histadrut would lose its seat, as a fair protest of Ariel Sharon's policies towards the Palestinian people. The China Labour Bulletin called this a "ploy" and stated that those who fell for it "are guilty of confusion, at best, and [of] a serious lack of principle at worst." Unfortunately, this move seemed to echo the attempt of some in the international labor movement who have advocated a process of "constructive engagement" with the ACFTU. ${ }^{102}$ An argument that these same activists dismissed with derision in the anti-apartheid movement is now welcomed despite the lack of any evidence that such "engagement" helps Chinese workers. The China Labour Bulletin condemns this approach as "the creeping legitimation" of the ACFTU.

\section{Global Labor's Approach to China}

As might be expected, the international labor movement has largely been very supportive of efforts to establish genuine, independent trade unions in China. The ICFTU has been a strong supporter of workers' rights in China, backing efforts to bring charges against the regime for violation of such rights at bodies like the ILO and providing resources to groups like the China Labour Bulletin and the Global Unions Liaison Office, both in Hong Kong. ${ }^{103}$ While the ICFTU's official "China Policy" statement of November 2002 recognizes that there are different views on how to approach China within the international labor movement, it notes that "China violates human, religious and workers rights on a massive scale, including the central enabling rights of freedom of association and collective bargaining." 104 Further, in the face of these differences, the ICFTU concluded that the ACFTU "is not an independent trade union organization and, therefore, cannot be regarded as an authentic voice of Chinese workers." It thus "reaffirm[ed] its request to all affiliates and Global Union Federations having contact with the Chinese authorities, including the ACFTU, to engage in critical dialogue... includ[ing] raising

101 Confusion at the ILO - China's Government Elected to Governing Body as. . . Worker Delegate, China LaB. Bull., June 19, 2002.

102 Id.

103 ICFTU Survey supra note 55; ICFTU Denounces Prison Sentences on Worker Rights Activists, ChIna Lab. Bull., May 12, 2003; Press Release, Int'l Confederation of Free Trade Unions, ILO Keeps Pressure on Several Anti-Union Governments, (Apr. 4, 2003) available at http://www.icftu..org/displaydocument.asp?Index= 991217407; Press Release, Int'l Confederation of Free Trade Unions, ICFTU China Policy: ICFTU Executive Board, (Nov. 27-29, 2002) available at http://www.icftu.org/ displaydocument.asp?Index=991217172 [hereinafter ICFTU China Policy].

104 ICFTU China Policy, id. 
violations of fundamental workers' and trade union rights in any such meetings, especially concerning detentions of trade union and labour rights activists." 105 Such a position of "critical" dialogue appears to lie somewhere in the middle of the range of relationships now found within international labor, which include everything from "no contacts" to "constructive dialogue." The ICFTU defines "critical" dialogue as including "raising violations of fundamental workers' and trade union rights in any such meetings, especially concerning detention of trade union and labour rights activists." 106

Somewhat surprisingly, however, some within the American labor movement, where a "no contacts" viewpoint has largely driven labor policy towards China, are now making an argument for a so-called constructive dialogue with the ACFTU that is precisely the kind of effort that so concerns the China Labour Bulletin about the possible "creeping legitimation" of that state body. Kent Wong, an American labor lawyer and former official of the Service Employees International Union and currently director of the UCLA Center for Labor Research and Education, Elaine Bernard, Executive Director of the Harvard University Trade Union Program and Gregory Mantsios of the Worker Education Center at Queens College of the City University of New York, have all recently advocated that the AFL-CIO should recognize the ACFTU. ${ }^{107}$

In the spring of 2002, Mantsios led a trip of U.S. academics and labor educators to China to meet with the ACFTU. He later issued a report calling for its recognition. ${ }^{108}$ Despite the evidence presented consistently over the last decade by Han Dongfang and other human rights organizations like Amnesty International and Human Rights Watch, Mantsios argued that the "ACFTU is an important advocate on behalf of [Chinese] workers." 109 A review of the report indicates that this delegation may have violated the ICFTU's official policy of critical dialogue with the ACFTU if and when such contact does take place, though admittedly that policy was only put in place after this particular trip. The Mantsios trip was undertaken "at the invitation" of the ACFTU and the delegation was "escorted throughout [their] trip" by the Deputy Head of the ACFTU's international department. ${ }^{110}$ Thus, there

105 Id. (emphasis added).

106 Id.

107 Wong \& Bernard, supra note 13; Leigh Jenkins, US unions resume talks after 20 years, South China Morning Post, Sept. 27, 2002; Gregory Mantsios, Tea for Two: Chinese and U.S. Labor: A Report from China, Fall/Winter 2002, New LAB. F. 61 [hereinafter Mantsios Report].

108 Mantsios Report, id. at 15.

109 Id. at 7.

110 Id. at 1. 
should be some initial concern that the information presented to the delegation was filtered to favor the Chinese government and that delegation members were not free to engage in an open dialogue with any Chinese workers they may have encountered. Indeed, Mantsios admits that "[b]ecause the delegation was visiting China at the invitation of the ACFTU, we did not meet with independent trade unionists, nor did we request to do so." The delegation "tried to compensate" for this deficit "by reviewing material written by independent activists." Of course, such material is widely available from organizations like the China Labour Bulletin, Amnesty International and Human Rights Watch and would hardly justify a trip to China.

Clearly the delegation had another goal. As Mantsios reports, "our purpose. . . was twofold: 1) to improve mutual understanding of our respective labor movements, and 2) to explore ways in which relations between the Chinese and U.S. labor unions could be improved." Thus, from the outset, before the delegation even left the United States, it had already concluded that the ACFTU constitutes a genuine labor movement. The trip, then, had a political goal, not a research or legitimate educational aim, despite having been organized by the university-based director of a worker education program and including in the delegation Kent Wong of UCLA, Elaine Bernard of Harvard, and Ruth Milkman, a UCLA sociology professor and Director of the newly established Institute of Labor and Employment at the University of California.

The Mantsios Report ignores, sidesteps or outright contradicts what is widely known about the status of worker rights and the role of the ACFTU in China today. At one point, for example, it states that "China's international agreements as well as its domestic labor and trade union laws provide important rights and protections. Workers in China have the right to join a union, to elect and remove union leaders democratically, and to strike against an employer."111 The only source for these almost laughable conclusions is a reference to the recent ratification by China of the International Covenant on Economic, Social and Cultural Rights and a note that "other union rights are embedded in China's Trade Union Law, revised in 2001."112

What do these laws actually indicate? Since the ACFTU exists to defend the interests of the state it cannot, of course, be called a genuine trade union and that is the conclusion reached by the ICFTU in its China Policy Statement promulgated in late 2002. By law, the ACFTU enjoys a legal monopoly; ${ }^{113}$ there are no legally protected union alternatives for

$111 \quad$ Id. at 9.

112 Id. at 17.

113 See discussion supra note 58. 
Chinese workers. Efforts to form alternatives to the ACFTU have been met consistently with the full force of state power. The Trade Union Law, instead of protecting the freedom of association, establishes a strict organizational hierarchy which requires each level of union organization in the country to submit to the will of the next higher level of organization, culminating in the ACFTU, "which shall be established as the unified national organization." 114

In fact, all of the sections of the Chinese labor organization are mandated to follow "the principle of democratic centralism," a hallmark of undemocratic Stalinist regimes. ${ }^{115}$ While the Law states that worker assemblies "shall have the right to remove or recall"116 union representatives, the "trade union organization at a higher level shall exercise leadership over a trade union organization at a lower level."117 Further, new local unions can only be established with the "approval" of "the trade union organization at the next higher level." 118 Finally, union financial resources are controlled jointly by the ACFTU and the Chinese state. ${ }^{119}$ Thus, the China Labour Bulletin concluded that "[i]ndependent trade unionists in China will find nothing to celebrate in [the new] legislation that guarantees the finances of an official trade union with a legal monopoly on organising." 120

The Trade Union Law does not contain any mention of the right to strike, and the explicit affirmation of this right once found in the Chinese constitution was deleted in 1982. As the ICFTU concluded in its 2003 Annual Survey of Violations of Trade Union Rights, "the right to strike was removed from China's Constitution in 1982 on the grounds that the political system in place had 'eradicated problems between the proletariat and enterprise owners." "' 121 In fact, according to one leading scholar of the Chinese labor movement, the elimination of the right to strike was a reaction by the regime to a wildcat strike wave that hit China in the wake of the emergence of Polish Solidarity in 1980 and $1981 .{ }^{122}$ Instead, China's Labor Law only provides that "where a labour dispute. . takes place, the parties concerned may apply for mediation or

114 See arts. 9-12, Trade Union Law of the People's Republic of China (2001), Adopted at the 5th Session of the 7th National People's Congress on Apr. 3, 1992, amended in accordance with the Decision on Amending the Trade Union Law of the PRC made at the 24th Meeting of the Standing Committee of the 9th National People's Congress on Oct. 27, 2001.

115 See id. art. 9.

116 Id.

117 Id.

118 See id. art. 11.

119 See id. art. 42-44.

120 Analysis of the New Trade Union Law, supra note 71.

121 ICFTU SURVEY supra note 57.

122 Labor Insurgency, supra note 79, at 49. 
arbitration or take legal proceedings according to law, or may seek for a settlement through arbitration." ${ }^{23}$

It is true that the ICESCR does recognize both the right of individuals "to form trade unions and join the trade union of his choice. . . [and] the right to strike." ${ }^{\prime 24}$ China ratified the ICESCR in 2001. However, the right to strike in the ICESCR is limited by a proviso which states that the right exists "provided that it is exercised in conformity with the laws of the particular country." Given the severe constraint on the right to strike in China in law and practice it seems unlikely that any worker can hope to take refuge in the ICESCR. Even if one could read the ICESCR to override the absence of the right to strike inside China, it is not a self-executing agreement and thus does not automatically become law inside China upon ratification but explicitly requires China "to take steps. . . including particularly the adoption of legislative measures. . . with a view to achieving progressively the full realization of the rights recognized in the present Covenant." ${ }^{125}$ Far from taking such steps, China appears to have moved away from its apparent commitment to genuine trade union freedom. Mantsios' sweeping conclusion that the right to strike actually exists in China by virtue of the ICESCR and the Trade Union Law is thus unwarranted. Further, upon joining the ICESCR, China issued a specific reservation, as it is allowed to do under international law, that "the application of Article 8.1 (a) [the right of workers to form trade unions and join unions of their own choice] of the Covenant to the People's Republic of China shall be consistent with the relevant provisions of the Constitution of the People's Republic of China, Trade Union Law of the People's Republic of China and Labor Law of the People's Republic of China." ${ }^{126}$ Thus, the monopoly of the ACFTU has been explicitly preserved.

In the fall of 2002, following the release of the Mantsios Report, UCLA's Kent Wong also led a trip to China, bringing with him, among others, Andy Stern, the President of the Service Employees International Union, and Tom Rankin, President of the California Labor Federation. This group met only with ACFTU representatives, not with independent union activists. A report on the visit appeared in the South China Morning Post in which Kent Wong called for a "dialogue" with the ACFTU and argued that "reopening lines of communication" would

123 Sec. 77, Ch. X, Labor Law of the People's Republic of China, Adopted at the 8th Meeting of the Standing Committee of the 8th National People's Congress on Jul. 5 , 1994, promulgated by Order No. 28 of the President of the People's Republic of China on Jul. 5, 1994, and effective as of Jan. 1, 1995. (Emphasis added.)

124 ICESCR, supra note 15 , art. 8.

125 ICESCR, supra note 15 , art. 2.

126 Declarations and Reservations, International Covenant on Economic, Social and Cultural Rights, Feb. 5, 2002, U.N. Treaty Collection (on file with author). 
"better serve the interests of U.S. companies" investing in China. ${ }^{127}$ These statements received a quick and sharp rebuke from Barbara Shailor, the director of the AFL-CIO's Department of International Affairs, who wrote a letter to the editor of the Morning Post stating that the Wong-led group was not an official AFL-CIO delegation and that the AFL-CIO shares the official view of the international labor movement that "the ACFTU is not an independent trade union but rather part of the Chinese government and party structure."128

The viewpoint of Wong, Bernard and Mantsios has yet to gain wider traction in the American labor movement but it is symbolic of the intellectual problem that the current situation poses. A detailed analysis of the pitfalls of "constructive engagement" by organized labor with authoritarian regimes was undertaken by the International Union of Foodworkers, the official international body representing union organizations in the food industry, in 1997. An IUF Mission to Hong Kong and China, which did meet with many independent Chinese unionists, reached very different conclusions than these individuals. Consistent with the analysis presented here, which indeed relies in part on the work of the IUF Mission, the Mission noted that, first, "the ACFTU remains a subordinate organisation under tight party control, with no autonomy whatsoever"129 and therefore a "dialogue between the ICFTU (or any other democratic trade union organization, also at national level) and the ACFTU is not a dialogue between two trade union organisations but between a trade union organisation on the one hand and a state organization on the other." ${ }^{\text {130 }}$ Furthermore, the IUF Mission concluded that "[a]ll informed observers concur that there is no possibility of the ACFTU evolving into an independent organisation by itself. ... [T] here would have to be serious division in the party and the emergence of a strong reformist-progressive tendency prevailing over the party conservatives. . . it is certainly not visiting foreign trade unionists who will influence the outcome of such political struggles." likely stasis in the character of the ACFTU, the "China issue is too important and it [is] too complex to be handled by persons unprepared for the task. Participants in delegations have to take the time to be briefed in depth. ... Chinese democratic trade unionists [including the Hong Kong Confederation of Trade Unions and Han Dongfang of the China Labour Bulletin] as well as NGOs with specific relevant expertise, should be involved in preparing any dialogue and in the discussions

\footnotetext{
127 Jenkins, supra note 107.

128 Barbara Shailor, Letter to the Editor, South China Morning Post (on file with author).

129 IUF Mission to China, supra note 68, at 29.

130 Id. at 39.

131 Id. at 30 .
} 
themselves." ${ }^{132}$ Finally, the Mission concluded that "[f]ull support, politically and financially, should be extended to Han Dongfang and other Chinese democratic trade unionists, by the ICFTU, ITSs (International Trade Union Secretariats) and national trade union organisations in a position to do so." ${ }^{133}$

Unfortunately, these core conclusions of a major international labor body appear to have been either readily ignored or violated by both the Mantsios and Wong delegations. In the face of widespread evidence they argued that the ACFTU is a genuine trade union and brushed aside the political situation in China today. They ignored Han Dongfang and consciously chose not to meet with dissident labor activists, while shaking the hands of those very individuals who are responsible for the repression of a genuine labor movement in China today. In light of the vigorous efforts of many thousands, if not millions, of Chinese workers such as Xiao Yunliang and Yao Fuxin to express their basic human rights to freedom of speech and association, it seems tragic that those in a position most capable of providing them support and encouragement at this crucial turning point in Chinese history willfully ignore them and, instead, present a distorted picture of Chinese reality to the outside world. An alternative view must be articulated if Chinese and western workers are to join together to reverse the "race to the bottom."

132 Id. at 40.

133 Id. at 42. 